\title{
Fishes of southern South America: a story driven by temperature
}

\author{
V. E. Cussac · D. A. Fernández · S. E. Gómez • \\ H. L. López
}

Received: 17 December 2007 / Accepted: 30 March 2008/Published online: 16 April 2008

(C) Springer Science+Business Media B.V. 2008

\begin{abstract}
The latitudinal extension of southern South America imposes a thermal gradient that affects the structure of marine and freshwater fish assemblages and the biology of the species through direct exposure to the temperature gradients or by means of a web of historical and ecological relationships. We have reviewed biological and ecological data of marine and freshwater fishes from the southern Neotropics, including Patagonia, and report several examples of dependence on temperature, from glacial times to today's climate change. We were able to identify historic and present effects on the diversity of fish assemblages, isolation, southern limits for the distribution of species, and
\end{abstract}

V. E. Cussac $(\bowtie)$

Instituto de Investigaciones en Biodiversidad y Medio Ambiente (INIBIOMA), Universidad Nacional del Comahue-CONICET, Calle Quintral 1250, Bariloche 8400, Río Negro, Argentina

e-mail:vcussac@crub.uncoma.edu.ar;

vcussac@yahoo.com

D. A. Fernández

Centro Austral de Investigaciones Centificas (CADIC)CONICET, Ushuaia, Tierra del Fuego, Argentina

\section{S. E. Gómez}

Museo Argentino de Ciencias Naturales "Bernardino Rivadavia"-CONICET, Buenos Aires, Argentina

\section{H. L. López}

Facultad de Ciencias Naturales y Museo, Universidad

Nacional de La Plata-CIC, Buenos Aires, Argentina morphological variation among populations. There is a wide range of characteristics that exemplify an adaptation to low temperatures, including biochemical peculiarities, physiological adjustments, and alternative life history patterns, and these appear in both freshwater and marine, and native and exotic fishes. The consequences of stable temperature regimes in both the ocean and thermal streams deserve special mention as these shape specialists under conditions of low selective pressure. At present, habitat use and interactions among species are being subject to changes as consequences of water temperature, and some of these are already evident in the northern and southern hemispheres.

Keywords Austral subregion · Autoecology · Biodiversity · Ecophysiology · Freshwater · Marine · Neotropical region - Thermal biology

\section{Fishes of southern South America: an overview}

Our knowledge of marine and freshwater fishes of southern South America has increased significantly in recent years (Menni et al. 1984; López et al. 2002; Baigún and Ferriz 2003; Menni 2004; López and Miquelarena 2005; Hubert and Renno 2006; Pascual et al. 2007; Aigo et al. 2008). A complete comprehension of their present status involves an understanding of tectonic plates, geological history (Cussac et al. 2004; Ruzzante et al. 2006), physiological constraints 
(Gómez 1996; Fernández et al. 2000; Johnston et al. 2003; Fernández et al. 2005), ecological interactions (Milano et al. 2002, 2006), alien species (Macchi et al. 1999, 2007), human impacts (Pascual et al. 2002; Ortubay et al. 2006), phylogeography, and molecular phylogeny (Johnston et al. 2003; Near et al. 2004; Zattara and Premoli 2005; Ruzzante et al. 2006).

Argentina has 47 freshwater native fish families, 184 genera (four endemic, one in the ParanoPlatensean Province), and 461 species (94 endemic) (Fig. 1). When political borders are ignored, more than $90 \%$ of the genera (170) are shared with Brazil, nearly 75\% (139) with Paraguay, 70\% (133) with Bolivia, and $60 \%$ (114) with Uruguay. However, when diversity is compared between Chile and Argentina, we can see the large effect of isolation due to the Andean orogeny northward of Chiloé Island (Dyer 2000) and the effect of homogenization produced southward of Chiloé (Cussac et al. 2004; Ruzzante et al. 2006; Pascual et al. 2007) due to extirpation, drainage change, and basin capture phenomena produced by glacial activity (Gagnon and Angers 2006).

The most dominant fishes among the many marine species present in the continental shelf of the Southern Ocean belong to sub-order Notothenioidei. These fishes have undergone an impressive adaptive radiation in Antarctic waters and currently comprise eight families and 129 species that inhabit Antarctic and sub-Antarctic waters (Eastman 1993, 2005). Outside of Antarctic waters, there are currently 28 species living in Patagonian, New Zealand, and Australian waters, with some species reaching as far north as $39^{\circ} \mathrm{S}$ (Buenos Aires Province) along the Atlantic Argentinean coast and $33^{\circ} \mathrm{S}$ (Valparaiso) along the Pacific Coast (Gosztonyi 1974; Pequeño 1989; Eastman 1993). The ancestral forms of the notothenioids are generally considered to have been a small temperate bottom-living species that lacked a swim bladder (Eastman 1993).

It is of course much to narrow a view to attempt to identify a common cause for this scenario-the adaptive radiation of these fishes. However, temperature has been recognized as one of the main cues to gaining an understanding of fish biogeography in southern South America (Ringuelet 1975; Quirós 1991; Menni and Gómez 1995; Gómez 1996). Life in water exists in a range of -2 to $50^{\circ} \mathrm{C}$, and no fish can avoid the effect of temperature on its metabolic rate
(Hill et al. 2006). Higher temperature enhances algal blooms, diminishes the concentration of oxygen in water, and increases the rate of organic matter degradation, thereby decreasing organisms' oxygen capacity and increasing oxygen demands (Wetzel 1983; Portner and Knust 2007). Integrating the growing amount of knowledge on South American fishes around such a causal factor with such a clear biological meaning could be useful. Consequently, the aim of this article is to review the influence of temperature in shaping fish communities along the climatic gradient in southern Argentina. The structure of this review is organized around six ecological and evolutionary processes: (1) physiological adaptation to extreme conditions, (2) decreasing freshwater fish diversity along a southward gradient, (3) life history variations throughout the gradient, (4) influence of temporal changes in climate on geological scales, (5) distribution, breeding, and temperature, and (6) global changes and climate warming.

\section{Physiological adaptation to extreme conditions}

Mean annual air temperature (www.smn.gov.ar) and surface seawater mean annual temperature ( www.hidro.gov.ar) decrease by more than $13^{\circ} \mathrm{C}$ from lattitude 25 to $55^{\circ} \mathrm{S}$ (Fig. 1), without any major differences arising between them. In lotic freshwater environments, the relationship between air temperature and water temperature is much more complex. For example, due to the drainage of freshwater from lower to higher latitudes, water temperature is $2-4^{\circ} \mathrm{C}$ warmer than air temperature in the Paraná-Paraguay basin (Menni and Gómez 1995), while Andean streams can be cooler than air due to their glacial origin. In lentic water bodies, when only local climate factors determine water temperature, positive linear relationships can be established between bottom water and mean annual air temperature (Quirós and Drago 1985; Quirós 1991).

Temperature affects the viability of populations at high latitudes or altitudes either through constraints to body size imposed by winter starvation conditions (Shuter and Post 1990) or directly by lethality (Fry 1971). The mismatch between the demand for oxygen and the capacity of the oxygen system to supply tissues is the primary mechanism that restricts an animal's tolerance to thermal extremes 
Fig. 1 Ichthyological ecoregions of Argentina (López et al. 2002). The groups of three black or white numbers are, respectively, autochthonous, endemic, and exotic fishes. Blue numbers and solid lines are isotherms of annual mean air temperatures ( www.smn.gov.ar). Marine references in blue numbers are annual mean surface water temperatures ( www.hidro.gov.ar). Data on species numbers of marine ecoregions were kindly provided by Juan Martín Díaz de Astarloa. Paranoplatensean Province: Misionerean ecoregion; , lower Uruguay River ecoregion; , subtropical Potamic Axis ecoregion; $\square$, eastern Paranoplatensean ecoregion; $\square$, gion; $\square$, western Paranoplatensean ecoregion; $\square$, Salado del SurVallimanca ecoregion; $\square$, Bonaerensean Atlantic ecoProvince: $\square$, subAndeanCuyan ecoregion. Patago-

Patagonian ecoregion;

Somuncurá ecoregion; area without records; $\leftrightarrow$, migratory displacement;

—, isotherms central Endorreic ecoreregion. Subandean-Cuyan nian Province:

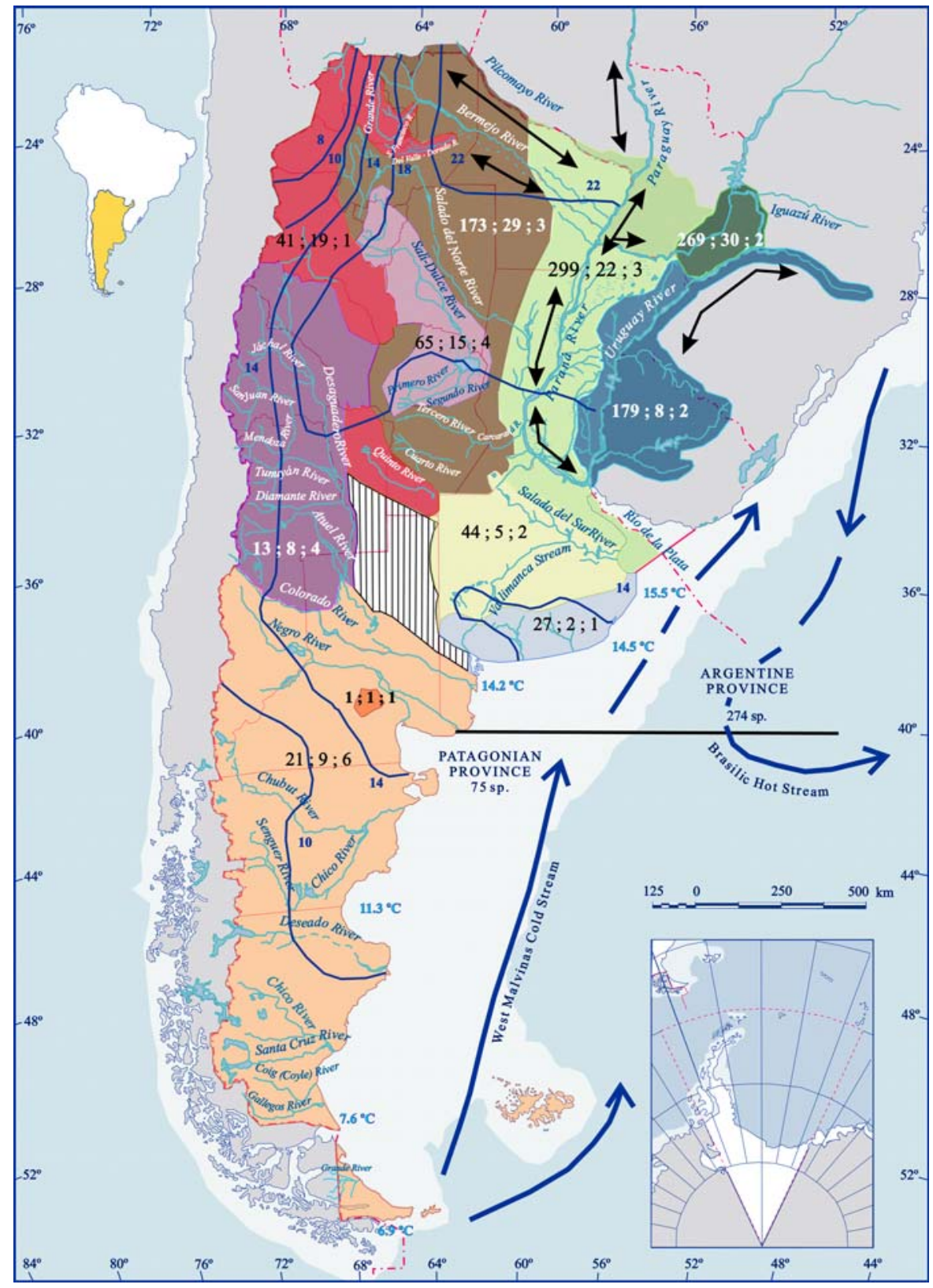

Ringuelet (1975) proposed that the impoverish(Portner and Knust 2007). The metabolic rate of ectothermic organisms depends on temperature and body size; this is particularly true for aquatic organisms since the change rate in the environmental temperatures experienced by them is buffered by the large thermal mass of water (Clarke and Johnston 1999). Temperature gradients produced by latitudinal or altitudinal changes create advantageous scenarios for geographic variations in metabolic rate (Conover and Schultz 1995). ment of fish fauna in the south of the Brazilic subregion was due to low temperature and high salinity. Lethal levels of low temperature correlate with the southern limit of the geographical distribution of several fish species (Gómez 1996). Moreover, the southward decrease of diversity correlates with water temperature (Menni and Gómez 1995). In restricted areas, the number of species correlates with salinity (Gómez and Ferriz 1998). The cichlids, 
which are very common in southern South America, tolerate high salinity. However, given the low salinity values of the Neotropical freshwaters where they live, their high tolerance to salinity $\left(>20 \mathrm{~g} \mathrm{l}^{-1}\right)$ is a 'relic' character of low or no adaptive value (Gómez and González Naya 2007). Similarly, in Lake Buenos Aires ( $46^{\circ} 32^{\prime}$ S, Fig. 1), the 'bagre' Hatcheria macraei shows a death temperature $\left(31^{\circ} \mathrm{C}\right)$ similar to that of a warm water fish, but a low equilibrium loss temperature $\left(22^{\circ} \mathrm{C}\right)$, suggesting that the high death temperature of $H$. macraei is a 'physiologic relic' related to previous warm water adaptation. A low equilibrium loss temperature can be seen as a product of the present thermal condition (Gómez 1990).

Early studies on Arctic and Antarctic fishes found resting metabolic rates that were greater than those predicted by extrapolation of the resting metabolic rate of temperate or tropical fish to polar temperatures. This was the origin of the concept of metabolic cold adaptation. However, there is no convincing evidence for such an elevated metabolic rate in polar fish (Steffensen 2002). Polar fish need long periods of time to acclimate to experimental apparatus and also to normalize oxygen consumption after post-prandial increases in oxygen consumption (Clarke and Johnston 1999). Similar long post-prandial times and not so high oxygen consumption values have been found in sub-Antarctic notothenioids (F. Vanella, personal communication).

Johnston et al. (2003) have shown that the radiation of Antarctic and sub-Antarctic notothenioids was associated with a progressive decrease in the body size-specific maximum number of fast fibers in the myotomal muscles of the more derived species, but not with a reduction in body size. Thus, if fiber sizebut not body size-is reduced, there should be an increase in the size of the muscle fibers. In actual fact, this group does have unusually large muscle fibers, with diameters that can reach $100 \mu \mathrm{m}$ in slow muscle and $500 \mu \mathrm{m}$ in fast muscle (Smialowska and Kilarsky 1981; Dunn et al. 1989; Battram and Johnston 1991; Fernández et al. 2000; Johnston et al. 2003; Fernández et al. 2005). This characteristic imposes obvious constraints in terms of oxygen diffusion and important metabolites, such as ATP, restricting muscle fiber size at least in aerobic fibers (slow twitch muscle fibers). Even if anaerobic muscle fibers (fast twitch muscle fibers) are powered by phosphagen hydrolysis and glycogenolysis - and therefore do not depend directly on diffusive fluxes-recovery is an aerobic process, and the rate of recovery will determine how quickly a new cycle of contraction and relaxation can occur. Large muscle fibers could have been favored in the evolution of notothenioids, since the decrease in the fiber surface to volume ratio will decrease the cost of maintaining ion homeostasis in these fibers. This idea, called the 'optimal fiber size hypothesis', was proposed by Johnston et al. (2003, 2004) for notothenioids and Arctic char evolution and by Kinsey et al. (2005) for blue crabs.

The mitochondrial volume density of mammalian skeletal muscles is normally below $10 \%$, but in fish this value can be more than 50\% (Guderley 2004). Fish living in cold temperatures have higher mitochondrial contents in their muscles than those living in warmer temperatures, with values reaching $60 \%$ in some Antarctic species (Johnston et al. 1988). Oxidative muscle fibers from species with similar life history traits show a significant negative relationship between mitochondrial volume density and habitat temperature; this is especially evident in demersal and moderately active species (Johnston et al. 1998). Thus, the primary mechanism for enhancing the aerobic capacity of muscle in cold-water fish is to increase the volume density of mitochondrial clusters (Johnston et al. 1998).

\section{The decrease in the South American freshwater fish diversity}

A decrease in fish diversity can be observed both from east to west and from north to south. Westward, fish diversity decreases from 79 to 41 species due to the absence of the Gymnotidae, Hemiodidae, Crenuchidae, Trichomycteridae, Lebiasinidae, and Aspredinidae families. In particular, the endorheic Salí-Dulce basin contains only 20\% of the ParanoPlatensean species (e.g., Clupeiformes and Beloniformes) and none of the big pimelodids (e.g., the 'surubíes' of the genus Pseudoplatystoma). Southward, the River de la Plata contains only $30 \%$ of the species of the Parano-Platensean Province. The Salado basin (Buenos Aires), being the southernmost limit of curimatids and loricarids, has only $10 \%$ of the species of the Parano-Platensean Province (Ringuelet 1955; López and Miquelarena 2005). This basin is a mixture of lentic and lotic water bodies and is 
characterized by a high variability and instability. Brazilic euryoic species of the families Clupeidae, Characidae, Pimelodidae, Callichthyidae, Anablepidae, Cichlidae, and Synbranchidae remain between $37^{\circ} \mathrm{S}$ and $39^{\circ} \mathrm{S}$ (Menni 2004). The great sea shore extension and the associated lentic and lotic water bodies allow for the presence of several euryhaline species. At a specific level, endemism is high in the Parano-Platensean Province, along the Paraná and de la Plata rivers. The highest number of endemic species has been described in the Iguazú basin, Alto Paraná Province (López et al. 2005).

Many different types of water bodies are present in Parano-Platense Province (Fig. 1), including large flood plain rivers (Pilcomayo and Bermejo, both of Andean origin, Paraguay, Paraná, and Uruguay), reservoirs, Pampasic and altiplanic 'lagunas', wetlands, deltas, endorheic basins, salt lakes, salt marshes, and estuaries (López and Miquelarena 2005). This province contains most of the species, genera, and families of Argentinean fauna, with a great variety of morphologies and life history traits and high endemism. The 'Pampa húmeda' is an extensive loess plain under an east-west climate gradient of decreasing rainfall westward of La Plata River and the Atlantic Ocean (about $63^{\circ} \mathrm{W}$, from $33^{\circ} 30^{\prime}$ to $38^{\circ} 30^{\prime} \mathrm{S}$ ). The most common lentic water bodies in this region are 'lagunas'. These third-order lakes maintain high salinity levels because of their marine origin or the increased east-west aridity gradient. They lack thermal stratification and show wide ranges of physical and chemical variables (Ringuelet 1962; Ringuelet et al. 1967; Gómez et al. 2007). The Paraguay, Paraná, and Uruguay rivers are faunal corridors that allow the southward dispersion of tropical and subtropical species (López and Miquelarena 2005), with trianglelike distribution areas (e.g., Anostomidae). Some places, such as headwaters, are characterized by the absence of some groups (e.g., Myliobatiformes, Clupeiformes, and Pleuronectiformes) that are usually present in the big rivers. Conversely, there are genera distributed only along the Paraguay-Paraná, Uruguay, and de la Plata rivers, such as the 'viejas' of the genus Hypoptopoma (Loricariidae) and the 'mojarras' of the genus Hyphessobrycon (Characidae).

We should be aware of the fact that the southward tendency of diversity decrease changes in Patagonia due to the presence of austral species of Galaxiidae and Percichthyidae and the presence of several species of salmonids (Pascual et al. 2007). However, the progressive southward disappearance of the 'otunos' Diplomystes cuyanus, D. viedmensis, and D. mesembrinus, the 'bagre' Trichomycterus areolatus, H. macraei, the Patagonian 'pejerrey' Odontesthes hatcheri and, finally, the 'perca' Percichthys trucha is noticeable. The lowest diversity occurs on Tierra del Fuego Island, the southernmost $\left(54^{\circ} \mathrm{S}\right)$ area of the world with freshwater fish fauna, where only salmonids (Becker et al. 2007; Pascual and Ciancio 2007) and four native species of the Galaxiidae family are found (Cussac et al. 2004; Liotta 2006; Milano et al. 2006).

\section{Life history variations throughout the gradient}

Temperature is not a significant cue for the migration of tropical freshwater fishes and seems to be related with migrations along La Plata basin only indirectly, mainly through food availability and gonadal cycles (see Menni 2004 for a review). Approximately ten Paranensean fishes are migratory, with movements of more than $500 \mathrm{~km}$ between 24 and $34^{\circ} \mathrm{S}$ (Fig. 1). The main species, the 'sábalo' Prochilodus lineatus, comprise $50 \%$ of the fish biomass of the basin (Sverlij et al. 1993), and they have retained their original seasonal pattern despite damming and changes in water discharge (Quirós and Vidal 2000).

A clear relationship between landlocked and diadromous life histories and latitude can be established for salmonids and galaxiids along a southward vector. The causes that favored these alternative life patterns seem to rely on the different thermal inertia of freshwater bodies and oceans. Consequently, low temperature has differential effects on freshwater and marine aquatic primary production and the opportunities for planktonic feeding (Gross et al. 1988), thereby favoring landlocked life at low latitudes and diadromy southward. The ability of the South American species of Galaxiidae to display diadromous or landlocked life history patterns along large latitudinal and altitudinal ranges (McDowall 1971; Cussac et al. 2004; Barriga et al. 2007; Boy et al. 2007; Lattuca et al. 2007) deserves attention. McDowall (1980) proposed that the adaptive value of anadromy was the escape from the cold Pleistocene winters. We should not expect that winter temperatures imply the same constraint for lacustrine (landlocked) or marine 
(diadromous) larvae. Unfortunately, the landlocked or diadromous character of galaxiids' populations has been clearly stated in only a few cases (Cussac et al. 2004; Boy et al. 2007; Lattuca et al. 2008). For example, McDowall (2003) reports only six lacustrine populations of the small 'puyen' Galaxias maculatus in South America and six in the Malvinas Islands. As McDowall (2001) pointed out, diadromy favors dispersion on the basis of straying and a lack of homing behavior, and landlocking favors speciation through local adaptation. However, landlocked $G$. maculatus has retained the ability to display several alternative life history patterns in relation to migration and the choice of reproduction sites (Chapman et al. 2006; Barriga et al. 2007; Boy et al. 2007). The salmonid species introduced into Patagonia (Pascual and Ciancio 2007) seem to follow the same pattern, with a 'spontaneous' establishment of anadromous populations of $O$. mykiss and chinook salmon Oncorhynchus tshawytscha (Pascual et al. 2001; Ciancio et al. 2005; Soto et al. 2007; D. Fernández et al., personal communication).

\section{Influence of temporal changes in climate on geological scales}

Isolation, empty niches, and thermal stability

Antarctica was affected by tectonic and oceanographic events that resulted in it becoming gradually isolated and colder and losing inshore shallow habitats due to the expansion of the ice sheet (Eastman 1993; Clarke and Johnston 1996). These events could have caused local extinctions of many of the Eocene components of the fish fauna, thereby reducing its diversity and leaving empty niches available to be occupied by groups that diversified in situ (notothenioids) or immigrated into this modified ecosystem (liparids and zoarcids) (Eastman 2005). There were, therefore, two main factors associated to diversification in Antarctic waters: fairly constant cold temperature and empty niches.

The evolution of antifreeze glycoproteins (17 million years ago according to Near 2004) is the most commonly accepted explanation for the success of the radiation of the Antarctic notothenioids, as these glycoproteins would have enabled the notothenioids to adjust to the climatic cooling that followed the opening of the Drake passage and the establishment of the Antarctic Polar Front some 20-25 million years ago (Cheng and DeVries 1991; Eastman 1993; Clarke and Johnston 1996). In agreement with this hypothesis are the findings that the most basal notothenioid families (Bovichtidae, Pseudaphritidae and Eleginopidae) are represented by non-Antarctic species (except for a single Antarctic bovichtid) with the plesiomorphic condition of lacking antifreeze glycoproteins (Eastman and Eakin 2000). Therefore, it is quite well established that a constantly cold environment was a characteristic predating the adaptive radiation of the notothenioids.

Similarly, lake populations in southwestern Argentina were established after the retreat of Pleistocene glaciers, probably after their last advance between 15,000 and 14,500 years B.P. Post-glacial lakes are relatively young environments where available ecological niches are likely to be present. Such lakes tend to have few species, partly because there has been little time or opportunity for colonization and partly because there has been even less time for in situ speciation to have occurred. Consequently, the organisms that do colonize these lakes are likely to encounter under- or unexploited resources and few competitors (see Ruzzante et al. 1998 for a review).

The 'perca' is widely distributed all along the Southern Andean and Patagonian regions of southern South America (López Arbarello 2004). The nominal species show a conspicuous morphological variation of the oropharyngeal apparatus-large and small mouths, and long and short gill rakes (Ruzzante et al. 1998) - that are related to resource use (Logan 2000). The variation patterns are different in different lakes (Ruzzante et al. 2003). Genetic studies have not yet found evidence of either specific differences or reproductive isolation between morphs (Ruzzante et al. 2006), and some findings suggest that environmental cues plays a major role in determining oropharyngeal development. This variation can be identified during the juvenile period (Ruzzante et al. 2003) and can also be observed among sibling larvae breeding in captivity, seemingly related with yolk amount (S. Crichigno, personal communication). Populations of 'perca' upstream and downstream of a hydroelectric dam can also show oropharyngeal differences, and these differences were identified within only a few years of the dam being built (Cussac et al. 1998). Similarly, 'perca' stocked in a 
fishless lake were successively named as different species throughout a 40-year period due to changes in their mouth shape, during which time drastic changes occurred in the lake's trophic web (Ortubay et al. 2006).

The case of the big 'puyen' Galaxias platei is different. This species is mostly restricted to montane lakes and streams of Patagonia, and it shows an extremely high endurance to low temperature and low oxygen availability (Milano 2003; Cussac et al. 2004) as well as major between-lakes variations in the morphology of the caudal peduncle. This variation can be correlated with the predation risk observed within each lake (Milano et al. 2002, 2006). Within the tolerance range, the capability to endure cold winters depends on being able to endure starvation (Shutter and Post 1990). In this context, $G$. platei seems to exploit the deep bottom of the lakes with scarce trophic competition or predation by other Patagonian fishes (Milano 2003; Cussac et al. 2004).

In accordance with their physiological and ecological distinctiveness, it would seem that glaciations affected $P$. trucha and $G$. platei in two different ways. 'Perca' distribution encompasses all Patagonian areas around the last glacial maximum (LGM) and $G$. plate $i$ is found deep inside this area. The colder water inhabitant, G. platei, underwent a strong bottleneck during the LGM. In contrast, the more warm-adapted and widely distributed $P$. trucha showed continuous population growth through the last two glacial cycles but went through an important bottleneck approximately $180 \mathrm{ka}$, which may have eliminated the eastern populations (Ruzzante et al. 2008).

Thermal stability, morphological reduction, and disaptation

Climate cooling has been a determinant factor for freshwater fish distribution in temperate areas. Following the Pleistocene glaciations, the Brazilic fish fauna of Patagonia was restricted to the thermal Valcheta Stream basin, in the Somuncurá Plateau (Menni and Gómez 1995). The Valcheta basin consists of two branches, both of which show a strong temperature gradient from the headwaters (20$26^{\circ} \mathrm{C}$ ) to the downstream waters $\left(17-18^{\circ} \mathrm{C}\right)$. Five species currently occur in the basin: the 'mojarra' Gymnocharacinus bergii (Characidae), which is one of the southernmost characids in the world and one of the two Characiformes present in Patagonia (Ringuelet 1975; Campos et al. 1996; Körber and Ortubay 2004), the southernmost populations of two mosquito fish, Cnesterodon decemmaculatus (Poecilidae) and Jenynsia multidentata (Anablepidae), and two exotic salmonids, the rainbow trout Oncorhynchus mykiss and the brook trout Salvelinus fontinalis (Ortubay et al. 1997). Gymnocharacinus bergii is a warm stenothermal fish that is on the endangered list (Ortubay et al. 1997; Ortubay and Cussac 2000) and, interestingly, none of the remaining four species occur in the headwaters of the stream (Miquelarena and Arámburu 1983). Although the high temperature might explain the absence of introduced salmonids, warm water conditions cannot account for the absence of the extremely eurytopic $C$. decemmaculatus and J. multidentata (Menni and Gómez 1995; Menni et al. 1996; Ortubay et al. 1997). Moreover, J. multidentata is known to coexist with several characin species in other small thermal springs (Menni et al. 1998). As an example of how behavioural traits and functional abilities interact with the thermal landscape, laboratory observations have revealed that the exclusion of $J$. multidentata from the headwaters of the Valcheta Stream seems to be due to the aggressive behavior of $G$. bergii, which is elicited to a large extent by $J$. multidentata's own agonistic behavior (Ortubay et al. 2002). The absence of C. decemmaculatus from the Valcheta headwaters could be related with their poor swimming capacity that places them at a disadvantage in the high-speed water current of these waters (Trenti et al. 1999).

Several adult structures have been reduced or modified in G. bergii, setting it apart from other characids as a monotypic subfamily (Miquelarena 1982). The reduction and loss of scales in adults is almost complete (Miquelarena and Arámburu 1983; Miquelarena et al. 2005) and the fright reaction has been modified (Lozada et al. 2000; Cordi et al. 2005). Stability and predictability of the environment favor specialization (Balon 1990), and low competition and low predation could diminish the negative selection pressure for any degenerative alleles, allowing important regressions in the structure and bodily functions (Peters and Peters 1983; Peters 1990; Peters et al. 1993). For example, studies of cave environments reveal the occurrence of morphological regression in species such as the cavedwelling form of Astyanax mexicanus and the blind 
cave catfishes Trogloglanis pattersoni, Satan eurystomus, and Pimelodella kronei (Langecker and Longley 1993; Trajano 1997). Examples of major regression phenomena in these Ostariophysi, in addition to the lack of pigmentation of cave dwelling Rhamdia quelen (Romero et al. 2002), suggest that regressive mutations could also have developed in particularly permissive habitats, such as the thermal Valcheta Stream (Miquelarena et al. 2005).

Notothenioids have unusual characteristics, including some events of disaptations (loss of evolutionary function) and adaptive recoveries (Montgomery and Clements 2000), that are associated to the successful adaptive radiation this group has undergone and to the special thermal conditions they experienced. The presence of these characteristics reinforces the theory of the radiation taking place inside Antarctic waters. For example, the Antarctic Trematomus bernachii and the sub-Antarctic (but with Antarctic origin) black cod Notothenia augustata lack the heat shock response, a set of genes that is activated in response to high temperature stress (Hofmann et al. 2000). Another example of disaptation-and one that was only possible due to the unusually cold and constant conditions of the Southern Ocean-is found in members of the Channichthyidae family, which has suffered the loss of the expression of significant quantities of hemoglobin and myoglobin (Cocca et al. 1995; Moylan and Sidell 2000; di Prisco et al. 2002; Cheng and Detrich 2007). All 16 species have lost most of the adult $\alpha \beta$-globin locus, retaining only a small fragment of the $\alpha$-globin gene, with the only exception being Neopagetopsis ionah, which possesses a disrupted $\alpha \beta$-globin gene complex that is non-functional (Near et al. 2006). Six of the icefish species fail to express myoglobin (Moylan and Sidell 2000). This loss of the respiratory hemoproteins was initially suggested to be a selectively neutral or even advantageous mutation if it resulted only in a reduction of the energy cost for blood circulation. Nevertheless, these losses have been determined to lead to a higher energetic cost for blood circulation and reduced cardiac performance (Sidell and O'Brien 2006). Moreover, the loss of respiratory pigments is associated with a set of compensatory adaptations in the heart and peripheral circulatory system (Tota et al. 1997), including a relatively large ventricular muscle mass (Johnston 1993) and a high blood volume (Acierno et al. 1995) coupled to a high-output cardiac pump operating at low frequencies and pressures (Tota et al. 1997). The development of compensatory physiological and circulatory adaptations in icefishes reinforces the hypothesis that the loss was probably maladaptive (di Prisco et al. 2002). Egginton et al. (2002) showed that structural adaptations in the circulatory system potentially enable a similar degree of tissue oxygenation over a $20^{\circ} \mathrm{C}$ range of environmental temperature in the nototheniids that would be overwhelming in the channichthyids due to the lack of respiratory pigments.

The ability to maximize performance in one environment was likely only be achieved at the cost of diminishing performance over a wider range of environments-i.e., a trade-off between generalist and specialist phenotypes (Wilson et al. 2002). Therefore, ectotherms from highly stable thermal environments, such as the Antarctic, should have a specialist phenotype that allow them to maximize performance at one temperature, while ectotherms from more variable thermal environments should possess more generalist phenotypes that maximize performance breadth. However, when the burst swimming performance in three species of Antarctic notothenioids was analyzed, Wilson et al. (2001) found a thermal performance breadth of at least $11^{\circ} \mathrm{C}$, which is similar to those shown by temperate fish species. In contrast, when these researchers analyzed sustained swimming in one of these Antarctic species, the performance breadth was only $5^{\circ} \mathrm{C}$ (Wilson et al. 2002). It is likely that the predicted trade-off only occurs for some key physiological process that is probably related to oxidative metabolism, such as sustained swimming, which relies on an adequate supply of $\mathrm{O}_{2}$ to the tissues. In contrast, burst swimming, which only involves oxidative steps in the recovery phase, is not affected by the trade-off. A more sophisticated analysis, however, showed a smaller thermal performance breadth in burst swimming for a sub-Antarctic notothenioid (Fernández et al. 2002).

\section{Distribution, breeding, and temperature}

The Bonaerensean 'pejerrey' Odontesthes bonariensis is a dominant species in the limnetic zone of the 'lagunas'. This ubiquitous species is highly valued as 
food and as a sport fish and has been introduced in natural and man-made water bodies in Argentina, Chile, Japan, and Italy since the beginning of the twentieth century (López et al. 1991). Gómez et al. (2007) defined the ranges and optimum values for water temperature and 16 water physical and chemical variables in relation to the geographical distribution of the species. The 'pejerrey' is a limnetic swimmer (Freyre and Protogino 1993), with a swimming speed estimated as three standard length $\mathrm{seg}^{-1}$ and a high metabolic rate (Gómez and Ferriz 2001). Similarly to the Patagonian 'pejerrey' $O$. hatchery (Cussac et al. 1992; Cervellini et al. 1993), it shows spatial and trophic ontogenetic niche shifts (S. Gómez and R. Ferriz, personal communication).

It is appealing to analyze the relationships between the Bonaerensean and the Patagonian 'pejerrey'. Both species have a remarkable tolerance to high salinity but not to sea water (Tsuzuki et al. 2000; Gómez and Ferriz 2001). Dyer (2000) and Menni (2004) agree in their view that both species were isolated by marine incursions several millions of years ago (Hubert and Renno 2006). At the present time, the distribution of these species overlaps due to the stocking of $O$. bonariensis in Patagonian and Andean lakes and reservoirs in the north of the distribution range of $O$. hatcheri (Liotta 2006). Both species hybridize in captivity (Strüssmann et al. 1997a) and, probably, also in the wild.

Could $O$. bonariensis overlap all of the distribution range of $O$. hatcheri? It must be noted that these species show a different degree of temperaturedependent sex determination (TSD; Strüssmann et al. 1997b), which supposedly confers an adaptive advantage to some species in a trade-off between intraspecific competition and genetic diversity (Hattori et al. 2007). Temperature-dependent sex determination could represent a differential constraint for both species, within the biogeographical range established by thermal tolerance and body size during the first winter.

Odontesthes bonariensis larvae survive at temperatures between 13 and $29^{\circ} \mathrm{C}$, but growth is negligible at 13 and $15^{\circ} \mathrm{C}$, and prolonged exposure to $29^{\circ} \mathrm{C}$ causes the disappearance of germ cells. In $O$. bonariensis, groups of fish exposed to about $17^{\circ} \mathrm{C}$ from the hatching to the juvenile stage become allfemale, whereas groups exposed to about $25^{\circ} \mathrm{C}$ become male-biased. The proportions of females are $100 \%$ at $13-19^{\circ} \mathrm{C}, 95 \%$ at $21^{\circ} \mathrm{C}, 81.2 \%$ at $23^{\circ} \mathrm{C}$, $29.4 \%$ at $25^{\circ} \mathrm{C}, 10 \%$ at $27^{\circ} \mathrm{C}$, and $0 \%$ at $29^{\circ} \mathrm{C}$. The survival of $O$. hatcheri is limited to temperatures between 13 and $27^{\circ} \mathrm{C}$ (only $8.7 \%$ at the latter temperature), with slow but steady growth at 13 and $15^{\circ} \mathrm{C}$. Strüssmann et al. (1997b) reported that the proportions of females were 88.9 and $89.5 \%$ at 13 and $15^{\circ} \mathrm{C}$, respectively, about $50 \%$ at temperatures between 17 and $23^{\circ} \mathrm{C}$, and $30.8 \%$ at $25^{\circ} \mathrm{C}$. It must be noted that these values show high agreement with the summer mean air temperatures (www.smn.gov.ar) of the distribution areas of each species (Liotta 2006).

\section{Global changes and climate warming}

The temperature increase attributable to the global change is considered one of the most important factors affecting the modification of freshwater systems (Roessig et al. 2004; Gooseff et al. 2005; Ficke et al. 2007). In some cases, global heating has produced an increment in mass deaths and a significant reduction of the fishing stocks (Kangur et al. 2007). During the last 40 years, the minimum mean annual temperature increased from 8.9 to $10.1^{\circ} \mathrm{C}$ in the the Salado River basin $\left(36^{\circ} \mathrm{S}\right)$, and the annual mean rainfall increased from 700 to $950 \mathrm{~mm}$ (Gómez and Menni 2005). The effects of these changes have been clearly observed in the formation of new communities of fish in areas that were formerly dry (Gómez et al. 2004). Conversely, decreases in the flow of the tropical rivers (Meisner and Shuter 1992) could affect the extension of flood plains, with a loss of breeding areas and an increase in mass fish deaths.

The exclusion of salmonids from the littoral zone due to an increase in water temperature at lake shores (Elliot 1981; Jansen and Hesslein 2004) seems to have occurred in Patagonia during the last 20 yearsto the benefit of $P$. trucha and the detriment of salmonid fish (Quirós 1991; Aigo et al. 2008). Salmonids are usually found both in littoral and limnetic zones, and P. trucha is usually found in the littoral zone (Macchi et al. 1999, 2007; Buria et al. 2007). Thus, interactions between salmonids and native Patagonian fishes, including trophic competition and predation, seem to be played out in the littoral zone of the lakes (Macchi et al. 1999). Thermal preferences of native Patagonian fishes are currently being studied. 


\section{Conclusion}

The examples we have reviewed show how temperature, through biochemical processes and ecological relationships, have affected and continue to affect fish evolution, distribution, and life history in the southern region of South America, explaining a great part of the present distribution and biological traits of extant species. We propose that these pieces of knowledge provide a palpable measure of the diversity and magnitude of the causal relationships between environmental temperature and individual fish and fish populations. Twenty thousand years after the last glaciation, climate change is currently presenting a new and faster thermal challenge to the fishes of southern South America, but now we know the causes and can-possibly—visualize the consequences.

Acknowledgements We thank the editors for providing us with a vehicle to promote some of our views. We would like to acknowledge the following institutions for granting previous and present projects that have enabled the elaboration of these ideas: Universidad Nacional del Comahue, CONICET and FONCYT (Argentina), Ministerio de Educación y Ciencia and Agencia Española de Cooperación Internacional (Grant CGL2004-01716, AECI, Spain), National Geographic Society (USA), and the NSF-PIRE award (OISE 0530267, USA) for support of collaborative research on Patagonian Biodiversity granted to the following institutions (listed alphabetically): Brigham Young University, Centro Nacional Patagónico, Dalhousie University, Darwinion Botanical Institute, Universidad Austral de Chile, Universidad Nacional del Comahue, Universidad de Concepción, and University of Nebraska. Justina Ponte Gómez kindly helped us with Fig. 1.

\section{References}

Acierno R, MacDonald JA, Agnisola C et al (1995) Blood volume in the hemoglobinless Antarctic teleost Chionodraco hamatus (Lönnberg). J Exp Zool 272:407-409

Aigo J, Cussac V, Peris S et al (2008) Distribution of introduced and native fish in Patagonia (Argentina): patterns and changes in fish assemblages. Rev Fish Biol Fish. doi: 10.1007/s11160-007-9080-8

Baigún C, Ferriz R (2003) Distribution patterns of native freshwater fishes in Patagonia, Argentina. Org Divers Evol 3:151-159

Balon EK (1990) Epigenesis of an epigeneticist: the development of some alternative concepts on the early ontogeny and evolution of fishes. Guelph Ichthyol Rev 1:1-48

Barriga JP, Battini MA, Cussac VE (2007) Annual dynamics variation of landlocked Galaxias maculatus (Jenyns 1842) population in a northern Patagonia river: occurrence of juvenile upstream migration. J Appl Ichthyol 23:128-135
Battram JC, Johnston IA (1991) Muscle growth in the Antarctic teleost, Nothothenia neglecta (Nybelin). Antarct Sci 3:29-33

Becker LA, Pascual MA, Basso NG (2007) Colonization of the Southern Patagonia ocean by exotic Chinook Salmon. Cons Biol 21:1347-1352

Boy CC, Morriconi E, Calvo J (2007) Reproduction in puyen, Galaxias maculatus (Pisces: Galaxiidae), in the southernmost extreme of distribution. J Appl Ichthyol 23: $547-554$

Buria L, Walde SJ, Battini M et al (2007) Movement of a South American perch Percichthys trucha in a mountain Patagonian lake during spawning and prespawning periods. J Fish Biol 70:215-230

Campos H, Gavilán JF, Murillo V et al (1996) Presencia de Cheirodon australe (Pisces: Characidae) en Lago Tarahuin (Isla Grande de Chiloé, $42-40^{\circ} \mathrm{S}$, Chile) y su significado zoogeográfico. Med Amb 13:69-79

Cervellini PM, Battini MA, Cussac VE (1993) Ontogenetic shifts in the feeding of Galaxias maculatus (Galaxiidae) and Odontesthes microlepidotus (Atherinidae). Environ Biol Fish 36:283-290

Chapman A, Morgan DL, Beatty SJ et al (2006) Variation in life history of land-locked lacustrine and riverine populations of Galaxias maculatus (Jenyns 1842) in Western Australia. Environ Biol Fish 77:21-37

Cheng CC, Detrich HW 3rd (2007) Molecular ecophysiology of Antarctic notothenioid fishes. Philos Trans R Soc London 362:2215-2232

Cheng CC, DeVries AL (1991) The role of antifreeze glycopeptides and peptides in the freezing avoidance of coldwater fish. In: di Prisco G (ed) Life under extreme conditions. G. d. Prisco/Springer, Berlin, Heidelberg

Ciancio JE, Pascual MA, Lancelotti J et al (2005) Natural colonization and establishment of a chinook salmon, Oncorhynchus tshawytscha, population in the Santa Cruz River, an Atlantic basin of Patagonia. Environ Biol Fish 74:219-227

Clarke A, Johnston IA (1996) Evolution and adaptive radiation of Antarctic fishes. TREE 11:212-217

Clarke A, Johnston NM (1999) Scaling of metabolic rate with body mass and temperature in teleost fish. $\mathrm{J}$ Anim Ecol 68:893-905

Cocca E, Ratnayake-Lecamwasam M, Parker SK et al (1995) Genomic remnants of alpha-globin genes in the hemoglobinless antarctic icefishes. Proc Natl Acad Sci USA 92:1817-1821

Conover D, Schultz ET (1995) Phenotypic similarity and the evolutionary significance of countergradient variation. TREE 10:248

Cordi V, Ortubay S, Lozada M (2005) Visual cues during the alarm reaction of Gymnocharacinus bergi (Pisces, Characidae). J Appl Ichthyol 21:487-491

Cussac VE, Cervellini PM, Battini MA (1992) Intralacustrine movements of Galaxias maculatus (Galaxiidae) and Odontesthes microlepidotus (Atherinidae) during their early life history. Environ Biol Fish 35:141-148

Cussac VE, Ruzzante D, Walde S et al (1998) Body shape variation of three species of Percichthys in relation to their coexistence in the Limay river basin, in Northern Patagonia. Environ Biol Fish 53:143-153 
Cussac V, Ortubay S, Iglesias G et al (2004) The distribution of South American galaxiid fishes: the role of biological traits and post glacial history. J Biogeogr 31:103-122

di Prisco G, Cocca E, Parker S et al (2002) Tracking the evolutionary loss of hemoglobin expression by the whiteblooded Antarctic icefishes. Gene 295:185-191

Dunn JF, Archer SD, Johnston IA (1989) Muscle fibre types and metabolism in post-larval and adult stages of Notothenoid fish. Pol Biol 9:213-223

Dyer B (2000) Systematic review and biogeography of the freshwater fishes of Chile. Estud Oceanol 19:77-98

Eastman JT (1993) Antarctic fish biology: evolution in an unique environment. Academic Press, New York

Eastman JT (2005) The nature of the diversity of Antarctic fishes. Pol Biol 28:93-107

Eastman JT, Eakin R (2000) An updated species list for notothenioid fish (Perciformes; Notothenioidei), with comments on Antarctic species. Arch Fish Mar Res 48:11-20

Egginton S, Skilbeck C, Hoofd L et al (2002) Peripheral oxygen transport in skeletal muscle of Antarctic and subAntarctic notothenioid fish. J Exp Biol 205:769-779

Elliot JM (1981) Some aspects of thermal stress on freshwater teleosts. In: Pickering AD (ed) Stress and fish. Academic Press, London

Fernández DA, Calvo J, Abercromby M et al (2000) Muscle fibre types and size distribution in sub-antarctic notothenioid fishes. J Fish Biol 56:1295-1311

Fernández DA, Calvo J, Wakeling J et al (2002) Escape performance in the sub-Antarctic notothenioid fish Eleginops maclovinus. Pol Biol 25:914-920

Fernández DA, Calvo J, Johnston IA (2005) Muscle growth in Antarctic and sub-Antarctic notothenioid fishes. Sci Mar 69:325-336

Ficke AD, Myrick CA, Hansen LJ (2007) Potential impacts of global climate change on freshwater fisheries. Rev Fish Biol Fish 17:581-613

Freyre LR, Protogino L (1993) Dos modelos de metabolismo energético de peces de agua dulce de Argentina. Gayana Zool 57:47-55

Fry FEJ (1971) Effects of environmental factors on the physiology of fish. In: Hoar WS, Randall DJ (eds) Fish physiology, vol 6. Academic Press, New York

Gagnon MC, Angers B (2006) The determinant role of temporary proglacial drainages on the genetic structure of fishes. Mol Ecol 15:1051-1065

Gómez SE (1990) Some thermal ecophysiological observations on the catfish Hatcheria macraei (Girard 1855) (Siluriformes, Trichomycteridae). Biota 6:89-95

Gómez SE (1996) Resistenza alla temperatura e salinitá in pesci della Provincia di Buenos Aires (Argentina), con implicazioni zoogeografiche. In: Paper IV Convegno Nazionale Associazione Italiana Ittiologi Acque Dolci. Trento

Gómez SE, Ferriz RA (1998) Una hipótesis de trabajo sobre la biología del pejerrey en la dinámica de las lagunas pampásicas. In: Ministerio de Asuntos Agrarios (ed) Primer Taller integral sobre el recurso pejerrey en la Provincia de Buenos Aires. La Plata

Gómez SE, Ferriz RA (2001) Algunos aspectos de la ecofisiología del pejerrey. In: Grosman F (ed) Fundamentos biológicos, económicos y sociales para una correcta gestión del recurso pejerrey. Astyanax, Azul

Gómez SE, Gonzalez Naya MJ (2007) Resistencia a la salinidad en dos especies de peces Neotropicales de la familia Cichlidae (Pisces, Perciformes). Mem Fundación La Salle de Ciencias Naturales 166:45-54

Gómez SE, Menni RC (2005) Cambio ambiental y desplazamiento de la ictiofauna en el Oeste de la Pampasia (Argentina Central). Biol Acuát 22:151-156

Gómez SE, Trenti PS, Menni RC (2004) New fish populations as evidence of climate change in former dry areas of the Pampa Region (Southern South America). Physis 59: 43-44

Gómez SE, Menni RC, Gonzalez Naya MJ et al (2007) The physical chemical habitat of the Buenos Aires pejerrey, Odontesthes bonariensis (Teleostei, Atherinopsidae), with a proposal of a water quality index. Environ Biol Fish 78:161-171

Gooseff MN, Strzepek K, Chapra SC (2005) Modeling the potential effects of climate change on water temperature downstream of a shallow reservoir, lower Madison River, MT. Climate Change 68:331-353

Gosztonyi AE (1974) Edad y crecimiento del róbalo Eleginops maclovinus (Osteichthyes, Nototheniidae) en aguas de la ria Deseado y sus adyacencias. Physis 33:1-8

Gross MR, Coleman RM, McDowall RM (1988) Aquatic productivity and the evolution of diadromous fish migration. Science 239:1217-1348

Guderley H (2004) Metabolic responses to low temperature in fish muscle. Biol Rev 79:409-427

Hattori RS, Gould RJ, Fujioka T et al (2007) Temperaturedependent sex determination in Hd-rR medaka Oryzias latipes: gender sensitivity, thermal threshold, critical period, and DMRT1 expression profile. Sex Dev 1: 138-146

Hill RW, Wyse GA, Anderson M (2006) Fisiología animal. Editorial Médica Panamericana, Buenos Aires

Hofmann GE, Buckley BA, Airasinen S et al (2000) Heatshock protein expression is absent in the antarctic fish Trematomus bernacchii (family Nototheniidae). J Exp Biol 203:2331-2339

Hubert N, Renno J-F (2006) Historical biogeography of South American freshwater fishes. J Biogeogr 33:1414-1436

Jansen W, Hesslein RH (2004) Potential effects of climate warming on fish habitats in temperate zone lakes with special reference to Lake 239 of the experimental lakes area, north western Ontario. Environ Biol Fish 70:1-22

Johnston IA (1993) Phenotypic plasticity of fish muscle to temperature change. In: Rankin J (ed) Fish ecophysiology. Chapman\&Hall, London

Johnston IA, Camm JP, White M (1988) Specialisations of swimming muscles in the pelagic Antarctic fish Pleuragramma antarcticum. Mar Biol 100:3-12

Johnston IA, Calvo J, Guderley H et al (1998) Latitudinal variation in the abundance and oxidative capacities of muscle mitochondria in perciform fishes. J Exp Biol 201:1-12

Johnston IA, Fernández DA, Calvo J et al (2003) Reduction in muscle fibre number during the adaptive radiation of notothenioid fishes: a phylogenetic perspective. J Exp Biol 206:2595-2609 
Johnston IA, Abercromby M, Vieira VL et al (2004) Rapid evolution of muscle fibre number in post-glacial populations of Arctic charr Salvelinus alpinus. J Exp Biol 207:4343-4360

Kangur A, Kangur P, Kangur K et al (2007) The role of temperature in the population dynamics of smelt Osmerus eperlanus eperlanus $m$. spirinchus Pallas in Lake Peipsi (Estonia/Russia). Hydrobiología 584:433-441

Kinsey ST, Pathi P, Hardy KM et al (2005) Does intracellular metabolite diffusion limit post-contractile recovery in burst locomotor muscle? J Exp Biol 208:2641-2652

Körber S, Ortubay S (2004) Literature published on the naked tetra Gymnocharacinus bergii (Characiformes: Characidae: Gymnocharacinae) from Patagonia, Argentina. Z Fischkunde 7:5-8

Langecker T, Longley G (1993) Morphological adaptations of the Texas blind catfishes Trogloglanis pattersoni and Satan eurystomus (Siluriformes: Ictaluridae) to their underground environment. Copeia 1993:976-986

Lattuca ME, Ortubay S, Battini MA et al (2007) Presumptive environmental effects on body shape of Aplochiton zebra (Pisces, Galaxiidae) in Northern Patagonian lakes. J Appl Ichthyol 23:25-33

Lattuca ME, Brown D, Castiñeira L et al (2008) Reproduction of landlocked Aplochiton zebra Jenyns (Pisces, Galaxiidae). Ecol Freshw Fish. doi:10.1111/j.1600-0633.2008.00292.x

Liotta J (2006) Distribución geográfica de los peces continentals de la República Argentina. Serie Documentos $N^{\circ}$, ProBiota. Facultad de Ciencias Naturales y Museo, Universidad Nacional de La Plata

Logan MS, Iverson SJ, Ruzzante DE et al (2000) Long term diet differences between morphs in trophically polymorphic Percichthys trucha (Pisces: Percichthyidae) populations from the southern Andes. Biol J Linn Soc 69:599-616

López HL, Miquelarena AM (2005) Biogeografía de los peces continentales de la Argentina. In: Llorente Bousquets J, Morrone JJ (eds) Regionalización biogeográfica en Iberoamérica y tópicos afines. Red Iberoamericana de Biogeografía y entomología sistemática (RIBES XII.ICYTED), Mexico City

López HL, García ML, Togo C (1991) Bibliografía de los pejerreyes argentinos de agua dulce. CIC, La Plata

López HL, Morgan CC, Montenegro MJ (2002) Ichthyological ecoregions of Argentina. ProBiota, Serie Documentos $\mathrm{N}^{\circ}$ 1, Universidad Nacional de La Plata

López HL, Miquelarena AM, Ponte Gómez J (2005) Biodiversidad y Distribución de la Ictiofauna Mesopotámica. In: Aceñolaza FG (ed) Temas de la Biodiversidad del Litoral Fluvial Argentino II. Univesidad Nacional del Tucumán, San Miguel

López-Arbarello A (2004) Taxonomy of the genus Percichthys (Perciformes: Percichthyidae). Ichthyol Explor Freshw 15:331-350

Lozada M, Ortubay S, Cussac V (2000) Fright reaction in Gymnocharacinus bergi (Pisces, Characidae), a relic fish from Patagonia. Environ Biol Fish 58:227-232

Macchi PJ, Cussac VE, Alonso MF et al (1999) Predation relationships between introduced salmonids and the native fish fauna in lakes and reservoirs in Northern Patagonia. Ecol Freshw Fish 8:227-2360
Macchi PJ, Pascual MA, Vigliano PH (2007) Differential piscivory of the native Percichthys trucha and exotic salmonids upon the native forage fish Galaxias maculatus in Patagonian Andean lakes. Limnologica 37:76-87

McDowall RM (1971) The galaxiid fishes of South America. Zool J Linn Soc 50:33-74

McDowall RM (1980) Freshwater fishes and plate tectonics in the southwest Pacific. Palaeogeogr Palaeoclimatol Palaeoecol 31:337-351

McDowall RM (2001) Diadromy, diversity and divergence: implications for speciation processes in fishes. Fish Fish 2:278-285

McDowall RM (2003) Variation in vertebral number in galaxiid fishes (Teleostei: Galaxiidae): a legacy of life history, latitude and length. Environ Biol Fish 66: 361-381

Meisner JD, Shuter BJ (1992) Assessing potential effects of global climate change on tropical freshwater fishes. GeoJournal 28:21-27

Menni RC (2004) Peces y ambientes en la Argentina continental. Monogr Mus Argentino Cienc Nat 5:1-316

Menni RC, Gómez SE (1995) On the habitat and isolation of Gymnocharacinus bergi (Pisces, Characidae). Environ Biol Fish 42:15-23

Menni RC, Ringuelet RA, Arámburu RA (1984) Peces marinos de la Argentina y Uruguay. Editorial Hemisferio Sur, Buenos Aires

Menni RC, Gómez SE, López Armengol F (1996) Subtle relationships: freshwater fishes and water chemistry in southern South America. Hydrobiologia 328:173-197

Menni RC, Miquelarena AM, Gómez SE (1998) Fish and limnology of a thermal water environment in subtropical South America. Environ Biol Fish 51:165-283

Milano D (2003) Biología de Galaxias platei (Pisces, Galaxiidae): especializaciones relativas a su distribución. $\mathrm{PhD}$ thesis. Universidad Nacional del Comahue, Buenos Aires

Milano D, Cussac VE, Macchi PJ et al (2002) Predator associated morphology in Galaxias platei in Patagonian lakes. J Fish Biol 61:138-156

Milano D, Ruzzante DE, Cussac VE et al (2006) Latitudinal and ecological correlates of morphological variation in Galaxias platei (Pisces, Galaxiidae) in Patagonia. Biol J Linn Soc 87:69-82

Miquelarena A (1982) Estudio comparado del esqueleto caudal en peces Characoideos de la República Argentina II. Familia Characidae Limnobios 2:277-304

Miquelarena A, Arámburu R (1983) Osteología y lepidología de Gymnocharacinus bergi (Pisces, Characidae). Limnobios 2:491-512

Miquelarena A, Ortubay S, Cussac V (2005) Morphology, osteology and reductions in the ontogeny of the scaleless characid Gymnocharacinus bergi. J Appl Ichthyol 21:510-518

Montgomery J, Clements K (2000) Disaptation and recovery in the evolution of Antarctic fishes. TREE 15:267-271

Moylan TJ, Sidell BD (2000) Concentrations of myoglobin and myoglobin mRNA in heart ventricles from Antarctic fishes. J Exp Biol 203:1277-1286

Near TJ (2004) Estimating divergence times of notothenioid fishes using a fossil-calibrated molecular clock. Antarct Sci $16: 37-44$ 
Near TJ, Parker SK, Detrich HW 3rd (2006) A genomic fossil reveals key steps in hemoglobin loss by the antarctic icefishes. Mol Biol Evol 23:2008-2016

Ortubay S, Cussac V (2000) Threatened fishes of the world: Gymnocharacinus bergi Steindachner, 1903 (Characidae). Environ Biol Fish 58:144-144

Ortubay SG, Gómez SE, Cussac VE (1997) Lethal temperatures of a Neotropical fish relic in Patagonia, the scale-less characinid Gymnocharacinus bergi Steindachner 1903. Environ Biol Fish 49:341-350

Ortubay S, Lozada M, Cussac V (2002) Aggressive behaviour between Gymnocharacinus bergi (Pisces, Characidae) and other Neotropical fishes from a thermal stream in Patagonia. Environ Biol Fish 63:341-346

Ortubay S, Cussac V, Battini M et al (2006) Is the decline of birds and amphibians in a steppe lake of northern Patagonia a consequence of limnological changes following fish introduction? Aquat Conserv 16:93-105

Pascual MA, Ciancio JE (2007) Introduced anadromous salmonids in Patagonia: risks, uses, and a conservation paradox. In: Bert $\mathrm{T}$ (ed) Ecological and genetic implications of aquaculture activities. Springer, Berlin Heidelberg, New York

Pascual M, Bentzen P, Riva Rossi C et al (2001) First documented case of anadromy in a population of introduced rainbow trout in Patagonia. Argentina Trans Am Fish Soc 130:53-67

Pascual M, Macchi P, Urbanski J et al (2002) Evaluating potential effects of exotic freshwater fish from incomplete species presence-absence data. Biol Invasions 4:101-113

Pascual MA, Cussac V, Dyer B et al (2007) Freshwater fishes of Patagonia in the 21 st century after a hundred years of human settlement, species introductions, and environmental change. Aquat Ecosyst Health Manage 10: 212-227

Pequeño G (1989) The geographical distribution and taxonomic arrangement of South American Nototheniid fishes (Osteichthyes, Nototheniidae). Bol Soc Biol Conc 60:183-200

Peters N (1990) Evolution without selection: quantitative aspects of the eye rudimentation in cave fishes. Mém Biospéleol 17:43-48

Peters N, Peters G (1983) Genetic problems in the regressive evolution of cavernicolous fish. In: Schröder JH (ed) Genetics and mutagenesis of fish. Springer, Berlin Heidelberg New York

Peters N, Schacht V, Schmidt W et al (1993) Gehirnproportionen und Ausprä gungsgrad der Sinnesorgane von Astyanax mexicanus (Pisces, Characinidae). Z Zool Syst Evolut-forsch 31:144-159

Pörtner HO, Knust R (2007) Climate change affects marine fishes through the oxygen limitation of thermal tolerance. Science 315:95-97

Quirós R (1991) Factores que afectan la distribución de salmónidos en Argentina. COPESCAL, FAO, Documento Técnico 9:163-173

Quirós R, Drago E (1985) Relaciones entre variables físicas, morfométricas y climáticas en lagos patagónicos. Rev Asoc Cs Nat Litoral 16:181-199

Quirós R, Vidal JC (2000). Cyclic behaviour of potamodromous fish in large river. In: Cowx IG (ed) Management and ecology of river fisheries. Fishing News Book, Blackwell Science, Oxford, pp 71-86

Ringuelet RA (1955) Panorama zoogeográfico de la provincia de Buenos Aires. Notas Mus La Plata Zool 18:1-15

Ringuelet RA (1962) Ecología acuática continental. EUDEBA, Buenos Aires

Ringuelet RA (1975) Zoogeografía y ecología de los peces de aguas continentales de la Argentina y consideraciones sobre las áreas ictiológicas de América del Sur. Ecosur 2:1-122

Ringuelet RA, Arámburu RH, Alonso de Arámburu A (1967) Los peces argentinos de agua dulce. Comisión de Investigaciones Científicas de la Provincia de Buenos Aires, La Plata

Roessig JM, Woodley CM, Cech Jr JJ, Hansen LJ (2004) Effects of global climate change on marine and estuarine fishes and fisheries. Rev Fish Biol Fish 14:251-275

Romero A, Sing A, McKie A et al (2002) Replacement of the troglomorphic population of Rhamdia quelen (Pisces: Pimelodidae) by an epigean population of the same species in the Cumaca cave, Trinidad, West Indies. Copeia 2002:938-942

Ruzzante DE, Walde SJ, Cussac VE et al (1998) Trophic polymorphism, habitat and diet segregation in Percichthys trucha (Pisces: Percichthyidae) in the Andes. Biol J Linn Soc 65:191-214

Ruzzante DE, Walde SJ, Cussac VE et al (2003) Resource polymorphism in a Patagonian fish Percichthys trucha (Percichthyidae): phenotypic evidence for interlake pattern variation. Biol J Linn Soc 78:497-515

Ruzzante DE, Walde SJ, Cussac VE et al (2006) Phylogeography of the Percichthyidae (Pisces) in Patagonia: roles of orogeny, glaciation, and volcanism. Mol Ecol 15: 2949-2968

Ruzzante DE, Walde SJ, Gosse JC et al (2008) Climate control on ancestral population dynamics: insight from Patagonian fish phylogeography. Mol Ecol. doi:10.1111/j.1365294X.2008.03738.x

Shuter BJ, Post JR (1990) Climate, population viability, and the zoogeography of temperate fishes. Trans Am Fish Soc 119:314-336

Sidell BD, O'Brien KM (2006) When bad things happen to good fish: the loss of hemoglobin and myoglobin expression in Antarctic icefishes. J Exp Biol 209: 1791-1802

Smialowska E, Kilarsky W (1981) Histological analysis of fibres in myotomes of Antarctic fish (Admiralty Bay, King George Islands, South Shetland Islands) I. Comparative analysis of muscle fibre sizes. Pol Pol Res 2:109-129

Soto D, Arismendi I, Di Prinzio C et al (2007) Establishment of Chinook salmon (Oncorhynchus tshawytscha) in Pacific basins of southern South America and its potential ecosystem implications. Rev Chil Hist Nat 80:81-98

Steffensen JF (2002) Metabolic cold adaptation of polar fish based on measurements of aerobic oxygen consumption: fact or artefact? Artefact! Comp Biochem Physiol A Mol Integr Physiol 132:789-795

Strüssmann CA, Akaba T, Ijima K et al (1997a) Spontaneous hybridization in the laboratory and genetic markers for the identification of hybrids between two atherinid species, Odontesthes bonariensis (Valenciennes, 1835) and 
Patagonina hatcheri (Eigenmann, 1909). Aquacult Res 28:291-300

Strüssmann CA, Saito T, Usui M et al (1997b) Thermal thresholds and critical period of thermolabile sex determination in two atherinid fishes, Odontesthes bonariensis and Patagonina hatchery. J Exp Zool 278:167-177

Sverlij SB, Espinach Ros A, Ortí G (1993) Sinopsis de los datos biológicos y pesqueros del sábalo Prochilodus lineatus (Valenciennes 1847). FAO-FIR S154:1-64

Tota B, Cerra MC et al (1997) The heart of the antarctic icefish as paradigm of cold adaptation. $\mathrm{J}$ Thermal Biol 22:409

Trajano E (1997) Threatened fishes of the world: Pimelodella kronei (Ribeiro, 1907) (Pimelodidae). Environ Biol Fish 49:332

Trenti PS, Gómez SE, Ferriz RA (1999) Capacidad de natación en tres peces pampásicos. Aprona 38:2-9

Tsuzuki MY, Aikawa H, Strüssmann CA et al (2000) Comparative survival and growth of embryosllarvaeland juveniles of pejerrey Odontesthes bonariensis and $O$. hatchery at different salinities. J Appl Ichthyol 16: 126-130

Wetzel RG (1983) Limnology, 2nd edn. Saunders College Publ, Philadelphia

Wilson RS, Franklin CE, Davison W et al (2001) Stenotherms at sub-zero temperature: thermal dependence of swimming performance in Antarctic fish. J Comp Physiol B 171:263-269

Wilson RS, Kuchela LJ, Franklin CE et al (2002) Turning up the heat on subzero fish: thermal dependence of sustained swimming in an Antarctic notothenioid. J Therm Biol 27:381-386

Zattara EE, Prémoli AC (2005) Genetic structuring in Andean landlocked populations of Galaxias maculatus:effects of biogeographic history. J Biogeogr 32:5-14 